Spring 2001

\title{
Robert Dahl and the Right to Workplace Democracy
}

\author{
Robert Mayer \\ Loyola University Chicago, rmayer@luc.edu
}

Follow this and additional works at: https://ecommons.luc.edu/politicalscience_facpubs

Part of the Political Science Commons

\section{Recommended Citation}

Robert Mayer (2001). Robert Dahl and the Right to Workplace Democracy. The Review of Politics, 63, pp 221-247. doi:10.1017/S0034670500031156.

This Article is brought to you for free and open access by the Faculty Publications and Other Works by Department at Loyola eCommons. It has been accepted for inclusion in Political Science: Faculty Publications and Other Works by an authorized administrator of Loyola eCommons. For more information, please contact ecommons@luc.edu. (c) (i) $\odot$

This work is licensed under a Creative Commons Attribution-Noncommercial-No Derivative Works 3.0 License. (c) University of Notre Dame, 2001. 


\title{
Robert Dahl and the Right to Workplace Democracy
}

\author{
Robert Mayer
}

Do employees possess a moral right to democratic voice at work? In A Preface To Economic Democracy and other writings over the past two decades, Robert Dahl has developed a neo-Kantian proof for the existence of such a right. Even if we accept the norm of distributive justice upon which Dahl founds his proof, voluntary subjection to authoritarian power in firms does not violate the legitimate entitlements of employees. While adult residents of territorial associations do possess a moral right to political equality, polities and firms are qualitatively different types of associations in which the entitlements of subjects are distinct. Subjection to power is acquired in different ways in the two kinds of associations, and this difference deprives employees—but not residents—of a right to democratic voice as a matter of moral desert.

Throughout his career, Robert Dahl has been troubled by the different ways in which those who govern polities and firms are chosen in modern society. While democracy is the norm in the state, at least in the advanced industrial nations, authoritarianism prevails in the economy. Most employees are subject to managers they did not elect and to rules in which they had little or no say. They are subordinates, a role manifestly at odds with the ideal of the democratic citizen. Given the "contradictions between our commitment to the democratic ideal and the theory and practice of hierarchy in our daily lives, ${ }^{11}$ Dahl has expressed interest from his earliest publications in reestablishing symmetry between polity and economy through the democratic transformation of work. Today Dahl is one of the most prominent advocates of workplace democracy in America, having devoted a book and numerous articles and chapters to the subject over the past six decades. ${ }^{2}$

1. Robert Dahl, "Liberal Democracy in the United States," in A Prospect of Liberal Democracy, ed. William Livingston (Austin: University of Texas Press, 1979), p. 68.

2. For Dahl's early interest in economic democracy see "On the Theory of Democratic Socialism," Plan Age 6 (1940): 325-56; "Workers' Control of Industry and the British Labor Party," American Political Science Review 41 (1947): 875-900; and Robert Dahl and Charles Lindblom, Politics, Economics, and Welfare (New York: Harper and Row, 1953), pp. 473-83. His most important normative writings on workplace democracy are After the Revolution?: Authority in a Good Society (New Haven: Yale University Press, 1970), pp. 115-40; "Power to the Workers?" New 
But although a consistent advocate of the democratic reorganization of work, Dahl's strategy of justification for this alternative has evolved during the course of his career. Until the middle 1970s, Dahl framed the argument for workplace democracy in terms of its relative desirability by contrast with the authoritarian firm. In After the Revolution?, for instance, Dahl was concerned to identify "the most desirable system of authority" in different kinds of associations according to the ability of a structure to optimize the values of personal choice, competence and economy. He argued that on this standard the "Corporate Leviathan" is "ludicrously far from optimal," given that it violates the criterion of personal choice, and that "self-management seems to me closer to the optimal than bureaucratic socialism or interest group management."

As Dahl began to develop a theory of procedural democracy in the later 1970s, however, a new method of justification for workplace democracy emerged alongside his earlier approach. In A Preface to Economic Democracy and other writings, Dahl now claimed that the self-managed firm is not merely desirable by contrast with the alternatives but is also a moral right of employees. According to this argument, labor is entitled to democratic voice in the firm as a matter of right, as a kind of compensation for subjection to the rules. In this way Dahl shifted the debate about workplace democracy from the question of its consequences to the question of what justice demands. If power at work is a moral right of employees, then it is the entitlements of the individual that matter and not merely the relative desirability of this set of arrangements. Moral rights must be

York Review of Books 15 (19 November 1970): 20-24; "Governing the Giant Corporation," in Corporate Power in America, ed. Ralph Nader and Mark Green (New York: Grossman Publishers, 1973), pp. 10-24; "On Removing Certain Impediments to Democracy in the United States," Political Science Quarterly 92 (1977) 1-20; Dilemmas of Pluralist Democracy: Autonomy vs. Control (New Haven: Yale University Press, 1982), pp. 126-33, 197-205; "Democracy in the Workplace: Is it a Right or a Privilege?" Dissent 31 (1984): 54-60; A Preface to Economic Democracy (Berkeley: Unversity of California Press, 1985); "Sketches for a Democratic Utopia," Scandinavian Political Studies 10 (1987): 195-206; Democracy and Its Critics (New Haven: Yale University Press, 1989), pp. 325-32; and "Economics, Politics, and Democracy," in Toward Democracy: A Journey (Berkeley: Institute of Governmental Studies Press, 1997), pp. 547-51.

3. Dahl, After the Revolution?, pp. 56, 140. 
respected even if they do not benefit others, and this means that if Dahl's later argument is correct, then the consequentialist one is of only secondary importance.

Dahl's moral-rights argument, however, is not persuasive. Democratic voice in the firm is not a right to which employees are morally entitled, or so I hope to show. In the following pages I critically examine Dahl's proof for the existence of a moral right to workplace democracy. I also review the counterarguments that have been advanced thus far, which suffer from their own weaknesses. I show that according to the norm of distributive justice Dahl himself accepts, voluntary subjection to authoritarian power in the firm does not violate the legitimate entitlements of employees. This is not true in political associations, for subjects of a polity are indeed entitled to democratic voice as a matter of right, if we accept that equals must be treated equally. Against Dahl, however, I insist that polities and firms are qualitatively different types of associations in which the entitlements of subjects are distinct. Subjection to power is acquired in different ways in the two kinds of associations, and this difference deprives employees-but not residents-of a moral claim to democratic voice.

While seeking to refute Dahl's moral-rights proof for workplace democracy, it is not my intention to contest his argument about its benefits. I am in fact sympathetic to arguments about the desirability of workplace democracy, although I am also skeptical that the wholesale democratization of work would be as unambiguously beneficial as Dahl and other advocates claim. ${ }^{4}$ The point, however, is that I agree that desirability is the proper ground upon which the issue should be decided. If the demos is

4. For examples of consequentialist justifications for workplace democracy see Herbert Croly, Progressive Democracy (New York: Macmillan, 1914), chap. 18; Carole Pateman, Participation and Democratic Theory (Cambridge: Cambridge University Press, 1970); Edward Greenberg, Workplace Democracy: The Political Effects of Participation (Ithaca: Cornell University Press, 1986); David Schweickart, Against Capitalism (Cambridge: Cambridge University Press, 1993); Samuel Bowles and Herbert Gintis, "A Political and Economic Case for the Democratic Enterprise," in The Idea of Democracy, ed. David Copp, Jean Hampton, and John Roemer (Cambridge: Cambridge University Press, 1993), pp. 375-99; and Christopher McMahon, Authority and Democracy: A General Theory of Government and Management (Princeton: Princeton University Press, 1994). 
persuaded that democratizing work is clearly advantageous, it should be entitled to mandate that reform because no moral rights are at stake. Conversely, if the demos is not convinced about the benefits of political equality at work, it should not be compelled to make the change in the name of protecting an alleged moral right. Within the firm, unlike the polity, the question of how power should be distributed cannot be resolved by appeal to the moral rights of the individual. It is a matter of discretion, and should be decided by a consequentialist calculation of the relative benefits. On the question of democratizing work, I believe, democratic deliberation should not be trumped by inflated rights-claims.

\section{Dahl's Proof}

Dahl's proof for the existence of a moral right to workplace democracy forms one part of his general theory of procedural democracy. Although first stated in several essays published in the late $1970 \mathrm{~s},{ }^{5}$ it received its fullest exposition in A Preface to Economic Democracy. In this section I explain Dahl's proof as set forth in that work.

A Preface to Economic Democracy makes both a moral-rights and a consequentialist argument for workplace democracy. If we disentangle the two, Dahl's proof for the existence of the right consists of three steps. The first specifies the conditions that must exist in an association in order to validate the claim to an equal share of power. The second step demonstrates that all of these conditions apply to economic associations. The third step addresses the objection that the moral right to workplace democracy violates another alleged moral right, that of owners to manage their property as they see fit.

5. "On Removing Certain Impediments to Democracy," pp. 10-12; and "Procedural Democracy," in Philosophy, Politics and Society, fifth series, ed. Peter Laslett and James Fishkin (New Haven: YaleUniversity Press, 1979), pp. 97-133. For criticism of Dahl's theory of procedural democracy and his replies see Phillip Green and Robert Dahl, "What Is Political Equality?: A Controversy," Dissent 26 (1979): 351-68; Richard Krouse, "Capitalism, Socialism, and Political Equality," Dissent 27 (1980): 453-56; Robert Dahl, "A Reply to Richard Krouse," Dissent 27 (1980): 456-58; and Augustus DiZerega, "Equality, Self-Government and Democracy: A Critique of Dahl's Political Equality," Western Political Quarterly 41 (1988): 447-68. 
Among advocates of workplace democracy, two different strategies have been employed in order to prove that democratic voice is a moral right of labor: some theorists make autonomy arguments, while others appeal to a principle of distributive justice. The argument from autonomy claims that voice in the firm is an instantiation of the moral right to autonomy all individuals possess. ${ }^{6}$ Distributive justice arguments, by contrast, attempt to show that an equal share of power in the firm is an entitlement of all who are subject to its rules. ${ }^{7}$ In the first step of his proof, Dahl develops an argument of the latter sort. ${ }^{8}$

Dahl's distributive justice proof is a variation of an argument first set forth by Carl Cohen thirty years ago. In a chapter on the justification of democracy, Cohen observed that the right to an equal share of power in an association can be deduced from two premises: "first, that equals should be treated equally; and second, that all members of that community are equal in the respect(s) properly relevant to the allocation of the right to participate in government. ${ }^{\prime \prime}$ The first premise is widely accepted but the second requires that members be equal with regard to stake and standing in the association in order to deserve equal voice in its governance. If both conditions hold, then democratic power is owed to members as a matter of distributive justice.

Dahl's list of the criteria entitling one to democratic voice in an association is essentially a more elaborate variation of Cohen's argument. In its first version, Dahl listed only two criteria that must exist in order to claim the right: first, that "there is a need for collective decisions that are binding on the members of the association"; and second, that the "members are roughly equally qualified, taken all around."10 Later versions of the argument

6. For examples of the autonomy argument see Patricia Werhane, Persons, Rights, and Corporations (Englewood Cliffs: Prentice-Hall, 1985), pp. 133-35; Carol Gould, Rethinking Democracy (Cambidge: Cambridge University Press, 1988), pp. 84-85, 143; and James Hyland, Democratic Theory: The Philosophical Foundations (Manchester: Manchester University Press, 1995), pp. 231-33.

7. For an example of the distributive justice argument see Michael Walzer, Spheres of Justice: A Defense of Pluralism and Equality (New York: Basic Books, 1983), pp. 291-303. For a critique of Walzer's argument see Robert Mayer, "Michael Walzer, Industrial Democracy, and Complex Equality," Political Theory 29 (2001): 237-61.

8. Dahl, Preface to Economic Democracy, p. 85.

9. Carl Cohen, Democracy (Athens: University of Georgia Press, 1971), p. 244.

10. Dahl, "On Removing Certain Impediments to Democracy," pp. 10-12. 
extended the list of criteria to seven, four of which concern the nature of the association and three the members who compose it. As Dahl puts it in A Preface to Economic Democracy, "the validity of a claim to this right rests on certain assumptions about the nature of a democratic association and the people in it." 11 The assumptions are (1) that the association's rules are "binding on all members of the collectivity"; (2) that there is a deliberative process before rules are adopted; (3) that "binding collective decisions ought to be made only by persons who are subject to decisions"; (4) that "the good of each person is entitled to equal consideration"; (5) that "each adult person in the association is entitled to be the final judge of his or her own interests"; (6) that "all the adult members of the association....are roughly equally well qualified to decide which matters do or do not require binding collective decisions"; and (7) that "when the claims of different persons to a scarce and valued thing are equally valid, and no person's claim is better or worse than any other's, then if the thing is appropriately divisible into equal shares (as, for example, votes can be divided), each equally qualified claimant is entitled to an equal share." 12

A moment's reflection reveals that the seventh item on Dahl's list corresponds to Cohen's first premise (that equals should be treated equally), while the other six specify the kinds of equal stake and standing that underwrite a democratic distribution of power (Cohen's second premise). Dahl's argument is that the seven items are an exhaustive list of the conditions necessary and sufficient to sustain a claim to an equal share of power in an association. The proof is conditional, taking an if-then form, but Dahl insists that "in any association for which the assumptions are valid, the members possess an inalienable right to govern themselves by means of the democratic process, whether or not they choose to exercise that right."13

Given the number of assumptions upon which the conclusion rests, it is easy to miss the underlying force of this proof. Its gist, however, can be simply stated: if equals should be treated equally, and members of a group are indeed equal in

11. Dahl, Preface to Economic Democracy, p. 57.

12. Ibid., pp. 57-58.

13. Ibid., p. 61. 
all relevant respects, then each is entitled as a matter of right to an equal share of power in the association. Like a geometric proof, the conclusion follows logically from the premises. As Cohen notes, if these conditions hold for an association, then "we have no rational way to justify any preference being given to some over others; upon him who would give such preference lies the obligation to justify such preference." ${ }^{14}$

Having specified the necessary and sufficient conditions for the entitlement to democratic voice, the second step in Dahl's argument is to show that all seven assumptions hold for economic associations. Dahl takes it for granted that the seven do hold for political associations, which means that residents of a polity possess a moral right to political equality. What Dahl must now prove is that employees are the moral equivalent of residents, a step Richard Arneson dubs "the parallel case argument.".15 By analogy, Dahl claims that the citizen is to a polity as the employee is to a firm. Hence, "if democracy is justified in governing the state, then it must also be justified in governing economic enterprises; and to say that it is not justified in governing economic enterprises is to imply that it is not justified in governing the state."16

Of the seven items enumerated in the first step, Dahl argues that only two are open to serious challenge as inapplicable in the firm: conditions one and six. The first assumption holds that for democracy to be an entitlement of members, they must be subject to binding decisions by the association. After all, if the decisions will not be enforced in any way, it does not really matter whether I have a say in them or not. Dahl notes that some may question the parallel case here because a firm's rules are not binding in the same way as the laws of a polity. "Unlike citizens of a state, one might object, workers are not compelled to obey managerial decisions; their decision to do so is voluntary."${ }^{17}$ The state claims a monopoly over the legitimate means of violence within a territory and uses that coercive power to enforce its laws, whereas the firm does not. A business can only fire me if I break its rules,

14. Cohen, Democracy, p. 245.

15. Richard Arneson, "Democratic Rights at National and Workplace Levels," in Copp, Idea of Democracy, p. 138.

16. Dahl, Preface to Economic Democracy, p. 111.

17. Ibid., p. 114. 
but the state can throw me in jail or even take my life, and this difference might suggest that the decisions of an economic association are not sufficiently binding to justify a right to democratic voice in their formulation.

Dahl counters, however, that this distinction is not relevant to the assumption in question. Decisions of an association are binding even if not coercively enforced as long as "severe sanctions" are imposed for noncompliance. The fact that a firm can fire me for disobedience, thus depriving me temporarily of a livelihood, is a serious enough sanction to render my decision to obey less than fully voluntary. Termination of membership is an exercise of power, and Dahl's point is that when power is exercised by associations over subjects, and the members are equals, then each has a right to an equal say in how that power is exercised. "Like a state, then, a firm can also be viewed as a political system in which relations of power exist between governments and the governed. If so, is it not appropriate to insist that the relationship between governors and governed should satisfy the criteria of the democratic process-as we properly insist in the domain of the state?"18

The sixth condition of the entitlement argument holds that the members must be equally qualified to make judgments about how the association should be run. In many respects this is the decisive premise of the argument for democracy, for if some are manifestly better able to discern the common good than others, it is not clear why the rest would be entitled to an equal share of power in the association. This seems to have been one of Plato's objections to democracy, for instance. Dahl recognizes that a modern-day, corporate-capitalist Plato might contest the parallel case on precisely this score, arguing that stockholders and the managers they appoint are better qualified to make business decisions for the long-term good of the firm than rank-and-file employees. ${ }^{19}$

Dahl replies to this objection by appealing to the conclusions of empirical and theoretical economics. He notes that according to rational-choice theory, labor should care at least as much about the long-term good of the business as owners or managers since labor's exit options are usually more constrained:

18. Ibid., p. 115.

19. Ibid., pp. 116-17. 
the losses incurred by workers from the decline of a firm are normally even greater than those investors suffer; for it is ordinarily much easier and less costly in human terms for a well-heeled investor to switch in and out of the securities market than for a worker to switch in and out of the labor market. A moderately foresightful worker would therefore be as greatly concerned with long-run efficiencies as a rational investor or a rational manager, and perhaps more so. ${ }^{20}$

This theoretical prediction is confirmed by the actual behavior of worker-managed cooperatives. Dahl cites a number of empirical studies that conclude democratic firms do make rational economic decisions and are capable of saving and investing for the sake of long-term performance. ${ }^{21}$ Thus, the strong principle of equality does seem to be a plausible assumption. What is more, if the critics are right that employees are not qualified to manage their firms, then it surely follows that citizens are even less qualified to govern the state, given that employees almost always know more about the business for which they work than citizens do about public affairs. Most opponents of workplace democracy are not willing to go that far, however, for it would cost them the vote they cherish in the state. In the end Dahl reminds his readers that "the strong principle of equality does not require that citizens be equally competent in every respect. It is sufficient to believe that citizens are qualified enough to decide which matters do or do not require binding collective decisions....and on matters they do not feel competent to decide for themselves, [that] they are qualified to set the terms on which they will delegate these decisions to others. ${ }^{\prime 22}$

Having refuted these objections, Dahl maintains that the analogy between firm and polity holds, and that all seven assumptions underwriting the entitlement to democratic voice apply in full to economic associations. The last step in the argument is to show that the moral right to workplace democracy is not trumped by the claims of a superior moral right. The one candidate that might play this role is the right to property, which some allege would be violated if labor gains equal voice in the management of the firm. In a democratic workplace owners could

20. Ibid., p. 123.

21. Ibid., pp. 122-33. For further evidence on the performance of cooperative enterprise see Schweickart, Against Capitalism, pp. 88-136.

22. Ibid., p. 118. 
no longer boss employees around; indeed, it seems that employees would now be in a position to boss around owners and their physical assets, thus infringing on the rightful entailments of property.

Dahl denies, however, that the right to property is in fact a moral right at all. ${ }^{23}$ While granting that individuals do possess a moral right to economic liberty, he rejects the claim that the right to property is a direct instantiation of that moral right. The derivation of the right to property from the right to liberty involves a series of non sequiturs, and this suggests that ownership is a conventional right subject to democratic deliberation and redefinition. If in their current form property rights conflict with the right to workplace democracy, they must give way in order to preserve the inviolability of moral rights. In economic associations it is democracy that is trumps, not the ownership of assets, because power over people is morally non-negotiable.

With this argument Dahl claims that the moral right of labor to self-government has been sustained. The denial of democratic voice to employees in the workplace is therefore an injustice, a violation of the inalienable rights of the individual. The fact that it is sanctioned today by majority rule and majority opinion is no justification, for moral rights cannot legitimately be suspended by a show of hands. Though Dahl devotes the first chapter of $A$ Preface to Economic Democracy to a refutation of Tocqueville's claim that democracies are given to majority tyranny, ${ }^{24}$ the remainder of the book seems to prove that the tyranny of the majority is in fact pervasive where economic rights are concerned. Democratic citizens, the majority of whom are also employees of authoritarian firms, for some reason refuse to enforce the moral right they possess as individuals to political equality at work.

\section{Flawed Refutations}

Despite Dahl's stature as the premier democratic theorist in the postwar era, surprisingly little attention has been devoted to his proof for the existence of a moral right to workplace de- 
mocracy. Most of the reviews of A Preface to Economic Democracy passed over the issue in silence. Nonetheless, if one scours the literature one can find two different grounds upon which Dahl's argument has been challenged, but in my view neither of these refutations succeeds.

One objection is directed against the third step in Dahl's proof, on the relative inferiority of property rights. Jan Narveson, a noted libertarian philosopher, insists against Dahl that there is a moral right to private property and that it does trump the putative right to democratic voice at work. ${ }^{25}$ One would expect nothing less from a libertarian. The issues here are thorny, but fortunately we can spare ourselves the trouble of entering the thicket of property rights in which both Dahl and Narveson become entangled if we recognize at the outset that ownership of physical assets by itself never entails power to direct the labor of others, which is the question at hand. As Christopher McMahon observes,

Central to ownership is the right to exclude others from contact with an item. Ownership thus gives the owner of an item the right to control the uses to which others put it in the sense that he may veto any use of it proposed by someone else. But it does not give him any right to tell anyone to put that property to the use that he wants. It is not a right to command labor. ${ }^{26}$

Ownership by itself is not a sufficient moral license to confer authority on managers. Hence the fact that employers own all of the physical assets of a business does not entitle them to boss labor around. Conversely, a democratic reorganization of the enterprise would not confer power on labor to use another's property without the owner's consent. For this reason democratic rights and property rights are capable of peaceful coexistence, without the need to establish a hierarchy between them, since the one is concerned with power over people and the other with power over things. In an economic democracy owners could keep their property and workers would retain their voice, and their interactions in the marketplace would be governed by contract. Instead of capital hiring labor, in a democratic economy labor will

25. Jan Narveson, "Democracy and Economic Rights," Social Philosophy and Policy 9 (1992): 45-49.

26. McMahon, Authority and Democracy, p. 15. 
hire capital, leasing it at interest from owners, but owners might remain free to keep their property if they do not wish to put it to productive use. ${ }^{27}$

It is important to recognize, then, that the democratization of work need not entail the expropriation of any physical assets of owners. Dahl, certainly, cannot be portrayed as a bloodthirsty communist bent on expropriating the expropriators. What he wants to take from capital is not the right to control property but the power to command labor. To be sure, loss of this power does involve a kind of expropriation, but the victim of this "takings" is not capital but labor itself. When democracy at work is mandated, labor loses the right to sell voice in exchange for a job. Capital thereby loses the right to buy voice, but it is from labor that this asset is actually taken. If we think of voice as personal property, then it is true that workplace democracy conflicts with property rights, but the conflict is quite different from the one about which Dahl and Narveson disagree.

As a libertarian, Narveson is still likely to object to the expropriation of labor's right to sell voice to capital, but then again some libertarians also complain about preventing labor from selling itself into slavery. ${ }^{28}$ To a libertarian virtually everything is property, while inalienable rights are usually just an illegitimate restraint on free trade. For the rest of us, however, the loss of the right to treat our personal liberty as a marketable asset might seem like a gain, and the same could be said for the loss of the right to sell voice. At the very least it is important to recognize that the real conflict between property rights and democratic rights is different from the one Dahl and Narveson debate, and that step three in Dahl's proof is either unnecessary or must be reformulated. Denying moral status to property rights is less likely to be convincing once we learn that the "property" in question is voice and not merely physical assets.

The second objection to the validity of Dahl's proof is leveled against the first step, which sets forth the criteria necessary and

27. On labor hiring capital in economic democracy see David Ellerman, The Democratic Worker-Owned Firm (Boston: Unwin Hyman, 1990), p. 64.

28. On the libertarian justification for self-enslavement see Robert Nozick, Anarchy, State, and Utopia (New York: Basic Books, 1974), p. 331; and J. Philmore, "The Libertarian Case for Slavery," The Philosophical Forum 14 (1982): 43-58. 
sufficient to claim an equal share of power in an association. Richard Arneson. argues in effect that if we specify the first condition in Dahl's list more carefully, the parallel case fails because that condition is not usually met by economic associations. The condition in question concerns the existence of binding decisions, an assumption Dahl recognized might be contested by opponents. Arneson points to "the differential voluntariness of the individual's relationship to politics and to work," which he insists "strongly conditions the force of the individual's claim to a democratic say in each area." If one's subjection to power is voluntary, he argues, then there is no entitlement to democratic voice. Arneson measures the voluntariness of subjection, however, by the existence of exit options in the form of other economic or political associations to which one could feasibly move. The claim is that "the presence of significant exit options can weaken the parallel case argument." If I could go elsewhere but decide to stay, then my subjection to authoritarian power in an association is voluntary. Hence I am not entitled to political equality in it since I voluntarily submit to powerlessness. Arneson's conclusion is that "having options and enjoying democratic rights may be substitutes for one another." ${ }^{29}$

In a market economy labor usually has multiple employment opportunities. This is especially true in the labor-scarce economy of the past year, but it also holds in leaner times. It remains true even in the academic job market, despite the glut of labor. Though tenure makes many a professor feel like a serf, attached for life to the institution that granted it, the fact is that academics have other feasible employment opportunities of which they could avail themselves. I could quit my job tomorrow and become an adjunct instructor at three or four community colleges, or try to get a job teaching high school, or go into business as a freelance writer, or apply at McDonald's, and so on. I do not do so because my current job seems the best of the available options, but the existence of alternatives cannot be denied. This is Arneson's point: if I have options but nonetheless choose to stay put, my submission to powerlessness is voluntary and I cannot therefore complain that an injustice has been done to me. Though I might like my current job plus democratic voice to boot, I have not been wronged if no

29. Ameson, "Democratic Rights at National and Workplace Levels," pp. 138-43. 
employer offers it to me, any more than I have been wronged because no employer is willing to pay me a six-figure income for the skills I have to offer. The case would be different if I had no realistic options and so was forced to obey authoritarian power for want of an alternative. Then voice would be my right since subjection is no longer unambiguously voluntary. Arneson notes that this is usually the situation of citizens in the nation-state, where exit from the association is much more costly than in the labor market. It is for this reason that citizens but not employees are usually entitled to democratic voice: "The right to a democratic say in the domain of politics is meant to ensure that those consequences one cannot avoid will be tolerable overall and in the long run." 30

Despite this criticism we should note that Arneson does not so much refute Dahl's parallel case as reformulate it; in essence he rewrites the first assumption in such a way that it can still hold good in both polity and firm, though less frequently than Dahl claims. According to Arneson's revised version, the first assumption now states that the rules are binding if the exit options of members are sharply constrained. As Arneson himself admits, this could conceivably be true in the labor market, for example in an isolated one-company town. ${ }^{31}$ Because exit is costly in this case, labor would have a valid claim to a democratic share of power in the firm. Conversely, the assumption might not be met in an authoritarian polity if significant exit options exist. Arneson gives the example of two neighboring countries with a common culture from which exit is easy: "If one land is an autocracy and the other is a democracy, the fact that citizens in the autocracy have the low-cost option of moving to the democratic sister nation substantially lessens the argument that citizens of both lands have democratic citizenship rights that the autocratic order systematically violates." 32 And that example is not purely hypothetical: it holds for the great majority of local governments in America, from which exit is often easier than from one's job. If Arneson is right, most residents of local polities do not have a moral right to democratic voice since they can always move if they do not like the local dictatorship.

30. Ibid., p. 140.

31. Ibid.

32. Ibid. 
But this surprising conclusion should suggest to us that something is wrong with Arneson's restatement of the parallel case. My intuitions tell me that I am entitled to democratic voice in local government even if my exit options are great. ${ }^{33}$ The fact that I could easily move someplace else does not seem relevant to the entitlement, for municipalities as much as nation-states enforce rules against me. What is more, Dahl himself objects that the exit argument "exaggerates the differences between a worker's subjection to decisions made by the government of a firm and a citizen's subjection to decisions made by the government of the state." With regard to both types of associations, Dahl asks, "is not 'exit' (or exile) often so costly, in every sense, that membership is for all practical purposes compulsory?" Arneson rests his case on the existence of formal exit options, but Dahl points out that substantively these options are often hollow. He concludes that "because exit is so costly, membership in a firm is not significantly more voluntary or less compulsory than citizenship in a municipality or perhaps even in a country," ${ }^{\prime 34}$ and I am willing to concede the point to him. Although I do believe that Arneson is on the right track when he claims that the bindingness of rules is relevant to the distribution of power within associations, he errs in judging the extent of bindingness by the exit options of members.

The bindingness of rules, however, can be measured in another way. Ease of exit is one dimension, but a second overlooked by Dahl and Arneson alike concerns entrance into the association-for rules are binding not only if one lacks an exit option but also if one lacks the option not to be subject to the association in the first place. In other words, the manner in which subjection to rules is acquired conditions one's entitlement to voice in an association, and it is this circumstance rather than the presence of an exit option that undercuts the parallel case. Subjection is acquired in different ways in firms and polities, I will show in the following sections, and this difference invalidates the entitlement to political equality in firms as a matter of distributive justice.

33. The reasoning that underlies this intuition will be set forth in the next section.

34. Dahl, Preface to Economic Democracy, pp. 114-16. 


\section{Acquiring Subjection}

Generally speaking, subjection to the rules of an association can be acquired in one of two ways: either the subjection is optional or it is required. In the former case we say that individuals possess a "subjection option," which means that refusal to submit to the association leaves one free from subjection to its rules. Where subjection is optional one must join the association before its rules become binding. In associations in which subjection is required, by contrast, a subjection option is lacking. Here members do not join in order to become subject to the rules but are conscripted by the association. Subjection is imposed regardless of choice such that members are not merely subjects but are also subjected. They suffer an imposition initiated by the association. ${ }^{35}$

Now it is my claim that the presence of an exit option does not condition one's entitlement to voice in an association but the presence of a subjection option does. The first assumption in Dahl's seven-point list, on the bindingness of rules, should therefore read that a subjection option is lacking. Where subjection is required the proof holds, for if an association imposes rules on me regardless of choice, and equals must be treated equally, and we are equal in the relevant respects, then I have a moral right to an equal share of power in the association. The entitlement arises precisely from the fact that others first staked a claim to power over me but have no better claim to this power than I do. If power there must be, and equals must be treated equally, then an equal share of that power is my right. Those who initiated my subjection have no superior claim to the power, and we are therefore obliged to share this "common good" equally.

But if not, then not. Where prospective members possess a subjection option their subjection to the rules is not imposed

35. Throughout this section I avoid the language of "voluntariness" in describing organizations that accord a subjection option to prospective members. In their criticisms of Dahl's proof both Narveson and Arneson employ this terminology, but they fail to distinguish carefully between the different ways in which organizations can be voluntary. Freedom to leave is one dimension of voluntariness, but freedom not to be subject to the organization is another. We would do better to avoid this language entirely and focus on the kinds of options organizations accord to members. For reasons that will become clear in the next section, I also avoid the contested language of consent in building my argument. 
regardless of choice. They have an option to be a member or not, to join if the association will have them, and this means that the rules of the association do not bind in the same way where the option is lacking. Associations that recognize a subjection option on the part of prospective members do not conscript subjects but recruit volunteers. They make an offer, one element of which might be voicelessness in the governance of the association, but the voicelessness is not imposed without the option to refuse subjection. The terms of subjection are negotiated, and while the resulting distribution of voice may be unequal, that distribution does not violate the principle of justice upon which Dahl's proof is premised. That principle is not equal outcomes per se but equal treatment of equals, which is consistent with inequalities of voice in an association as long as subjection to the rules is authentically optional. Presumably associations that make unequal voice a condition of membership must offer some kind of compensation in return in order to attract subjects. ${ }^{36}$ Where a minimum degree of compensation is lacking we have reason to doubt the existence of a subjection option (an issue to which we will return in the next section), but where that minimum standard is met an unequal share of voice is not an injustice to members given the seventh assumption in Dahl's proof. It could only be so if equal outcomes are mandated from the start, but if that is the principle of fairness upon which the right to workplace democracy is predicated then the other six assumptions would be unnecessary. Dahl, however, is not a "simple egalitarian," to employ Michael Walzer's terminology, ${ }^{37}$ and it therefore follows from Dahl's own logic that voice is not an entitlement of members where a subjection option exists. Such members are not required to join or obey the rules,

36. The claim to political equality in an organization can be a valuable asset. Capitalist firms purchase the claim (negotiate political inequality) because they think they can maximize profits by dictating how the work will be done. Whether an authoritarian political structure in the firm in fact enhances profitability is a contested issue. If it does, then expropriation of this claim (by mandating workplace democracy in every firm) should result in diminshed compensation for labor. For two arguments along these lines see Ian Maitland, "Rights in the Workplace: A Nozickian Argument," Journal of Business Ethics 8 (1989): 951-54; and Michael Phillips, "Should We Let Employees Contract away Their Rights against Arbitrary Discharge?" Journal of Business Ethics 13 (1994): 233-42.

37. Walzer, Spheres of Justice, p. xii. 
and this means that the unequal voice they accept in entering the association cannot be construed as an injustice done to them.

A set of examples will illustrate the relevance of this distinction for the entitlement to equal voice in various associations. Take, first, the case of polities. Given my specification of the first assumption in Dahl's list, adult residents of territorial associations do possess a moral right to political equality. This is because residents are essentially conscripted by territorial associations and required to obey the rules regardless of choice. The myth of the social contract notwithstanding, polities do not ask residents whether they want to obey before subjection is imposed within a territory. Governments impose first and ask for consent later-if indeed they ever do. The power is simply claimed, but the rulers who claim sovereignty are no better than the adult residents subjected to it. Unless the power is shared equally, therefore, equals will not be treated equally. The norm of equality that governs the distribution will be violated, and an injustice done to voiceless subjects. Political equality is precisely the compensation equals are owed for the imposition of subjection.

But what of immigrants? Don't prospective newcomers to a territorial association possess a subjection option that would rob them of the entitlement to voice as a matter of distributive justice? If so, it seems that polities could legitimately require consent to voicelessness as a condition for admission to the territory. The result would be an unequal system of membership, in which native residents are full-fledged citizens while immigrant residents are merely subjects. This is the logic of guest-worker laws, which require some groups of newcomers to trade the claim to voice for the right of admission into the territory governed by the polity.

The existence of a subjection option for prospective immigrants, however, is an illusion-one that polities all too often foster in order to exploit vulnerable newcomers. It is an illusion because it mistakes entering a jurisdiction for joining an association or common enterprise. ${ }^{38}$ Immigrants do make a choice to change location, but moving is not the same as joining. When I

38. Consider the fruitful distinction drawn by Michael Oakeshott between civil and enterprise associations in On Human Conduct (Oxford: Clarendon Press, 1975), ch. 2. Polities are not enterprise associations, but they sometimes like to act as if they were. 
move from one residence to another in a different jurisdiction I am not given an option not to be subjected to that new jurisdiction, and it is precisely this choice that constitutes a subjection option. While nation-states may be entitled to block entry of aliens, we should not confuse permission to enter with bestowal of a subjection option that undercuts the entitlement to voice. Once some reasonable probationary period has elapsed, such that newcomers can be recognized as residents and not merely tourists or transients, immigrants (including guest-workers) must be accorded the same share of power enjoyed by natives. Equals must be treated equally, for what matters in polities is not the nativity of one's residency but the fact of subjection and its imposition regardless of choice. Natives of a territory are not given a choice by the polity about whether to be subjected or not, and so to appeal to the principle of choice for this subset of residents (immigrants) is an injustice given the norm of equal treatment and the assumption of equal competence ${ }^{39}$

Another example that illustrates the relevance of conscription or imposed subjection to the entitlement to democratic voice is unionization in the closed shop. When membership in a union is required as a condition of employment a subjection option is lacking and the members are therefore entitled to self-government. Subjection to the rules, including the payment of dues, is imposed, and voice is the compensation owed for this imposition. The fact that one could avoid subjection by not taking the job is irrelevant to the entitlement, for membership in the firm and in the union must be distinguished. In accepting employment I am automatically conscripted by the union regardless of choice, and since it initiates the subjection I am entitled to an equal share of the power in return. This type of organization does not have the discretion to withhold voice from me.

But other types of associations, even if they consist of equally competent individuals, do possess such discretion because they accord a subjection option to prospective members. Consider a classic example: a monastic institution. Monasteries, at least in the Catholic tradition, are not democratic organizations. Superiors are not chosen by those subject to the discipline, who in some

39. For a similar argument against guest-worker laws see Walzer, Spheres of Justice, pp. 56-61. 
orders are literally voiceless. Most people seem to believe that there is nothing intrinsically unfair about this radically unequal distribution of power and that initiates do not possess a moral right to political equality in the organization. But if we apply Dahl's version of the seven-point list to this case we might be forced to conclude against our intuitions that such a right does exist, even if members choose not to claim it. As in the case of the firm, only assumptions one and six might be contested. ${ }^{40}$ Regarding the latter, a conservative reading of Catholic theology might cast doubt on the strong principle of equality, but there is empirical evidence that laymen can govern religious organizations perfectly wellwitness the Quakers. And with regard to binding decisions, if difficulty of exit is the standard by which bindingness is measured then it seems plausible to conclude that the rules are binding since exit from the monastery is likely to be more difficult than exit from a firm, let alone a municipality. If so, monasteries ought to be democratic, but that is a conclusion most of us would reject. And the reason we reject it is precisely because initiates possess a subjection option that deprives them of the entitlement to voice. Novices opt to join an organization which they know is governed in an authoritarian fashion, and that option decisively conditions their entitlements. Subjection is not imposed regardless of choice, and thus voice is not owed as compensation for the subjection that is acquired.

The same logic applies even more straightforwardly to private clubs, where equal competence is widely assumed. Clubs do not have to be democratic, even in a democratic society. Founders are free to craft the governance structure they deem best, and new members have no moral right to require political equality where it does not exist as long as they have been accorded a subjection option. Once members are admitted they may press for democratic rights, but no fundamental injustice is done to them if equal voice is not granted. In organizations of this sort distributive justice does not dictate how power should be divided because subjection to the rules is not required.

40. In the example we abstract from the circumstance that the monastery belongs to a larger organization (the Church) that may be entitled to choose the superiors. Assume for the sake of argument that the monastery is autonomous. 
Having now identified the crucial assumption upon which the entitlement to political equality must be premised in order to be valid, we are now in a position to return to the parallel case. With Dahl I agree that equal voice is owed to adult residents of territorial associations as a matter of distributive justice. But do employees have the same entitlement? Are they also denied a subjection option?

\section{The Exploitation Objection}

On the face of it the answer seems easy: the parallel case fails because the typical employee does possess a subjection option. Unlike residents, employees are not conscripted, and for this reason they lack the moral right to political equality despite the other ways in which the two types of associations are equivalent. Only slaves and serfs would have a valid claim to democratic voice, but the position of labor in a capitalist market economy is qualitatively different because labor is not subjected to management regardless of choice.

The conclusion is drawn too quickly, however, for there is a familiar objection that challenges the existence of a meaningful subjection option for wage-labor in a capitalist economy. According to this view, the propertylessness of most workers and their dependence on capital for employment makes subjection in the firm a virtual requirement for the majority. ${ }^{41}$ While the labor market creates the appearance of choice, in the sense that one may apply to many different employers or even go into business for oneself, only a relative few have a realistic option of avoiding subjection to some capitalist firm or other. Given the intensity of competition and the advantages enjoyed by large-scale capitalist

41. The classic locus for this argument is, of course, Marx's Capital. At the end of the chapter on the working day, for instance, Marx observes that "our worker emerges from the process of production looking different from when he entered it. In the market, as the owner of the commodity 'labor-power,' he stood face to face with other owners of commodities, one owner against another owner. The contract by which he sold his labor-power to the capitalist proved in black and white, so to speak, that he was free to dispose of himself. But when the transaction was concluded, it was discovered that he was no 'free agent,' that the period of time for which he is free to sell his labor-power is the period of time for which he is forced to sell it" (Capital: Volume One, trans. Ben Fowkes [New York: Vintage Books, 1977], p. 415). 
enterprise, opportunities for self-employment are sharply constrained. As a result, we might conclude that wage-labor is effectively conscripted by capital, not individually but as a class. As G. A. Cohen explains, "since the freedom of each [proletarian] is contingent on others not exercising their similarly contingent freedom, we can say that there is a great deal of unfreedom in their situation. Though each is individually free to leave, [each] suffers with the rest from...collective unfreedom." ${ }^{42}$

If empirically accurate as a description of the plight of wagelabor this objection is valid, for exploited labor does lack a meaningful subjection option. A libertarian might challenge the very possibility of exploitation in a capitalist market, ${ }^{43}$ but I will acknowledge the force of the objection because I agree that exploitation renders the appearance of choice illusory. ${ }^{44}$ Nonetheless, even if we grant the objection it does not follow that exploited labor in a capitalist economy possesses a moral right to workplace democracy. A different conclusion is required by the logic of the objection.

In order to see this we must distinguish between two different meanings of the claim that subjection is required. According to the first version (required $)_{1}$, subjection occurs regardless of choice. Jurisdiction is simply claimed, such that subjects are effectively conscripts. It is my argument that subjection to polities is required in this sense. But subjection can be required in a different way $\left(\right.$ required $\left._{2}\right)$, if one formally possesses options but substantively the options are hollow. In this case subjection is acquiesced to because circumstances are such that subjection is the only viable (or the least bad) alternative. Here exploitation takes the place of coercion in rendering individuals subject to rules and decisions. ${ }^{45}$

42. G. A. Cohen, "The Structure of Proletarian Unfreedom," Philosophy and Public Affairs 12 (1982): 11.

43. For the libertarian objection see Nozick, Anarchy, State, and Utopia, pp. $250-65$.

44. On the theory of exploitation see David Zimmerman, "Coercive Wage Offers," Philosophy and Public Affairs 10 (1982): 121-45; John Roemer, A General Theory of Exploitation and Class (Cambridge: Harvard University Press, 1982); and Allen Wood, "Exploitation," Social Philosophy and Policy 12 (1995): 136-58.

45. According to Marx, expropriation of the direct producers results in the formation of "grouped masses of men who have nothing to sell but their laborpower" and "are compelled to sell themselves voluntarily....The silent compulsion of economic relations sets the seal on the domination of the capitalist over the worker" (Capital, p. 899). 
Now if subjection to capitalist management on the part of wage-labor is required ${ }_{2^{\prime}}$ a moment's reflection suggests that the appropriate redress for this imposition is not in fact an equal share of voice in the firm but rather the restoration of choice that has been unjustly constrained. If consent to subjection has been rendered hollow through the reduction of effective options, the proper remedy for this loss is to make consent robust again by enhancing labor's choices. According to the exploitation objection, labor loses its options because it is propertyless and thus compelled to accept disadvantageous offers under the pressure of necessity. In order to prevent exploitation workers above all need their own property, or at least guaranteed subsistence such that they never feel compelled to accept just any offer, no matter how bad. The proper cure for exploitation, then, is not workplace democracy but a generous welfare state, or, more radically, redistribution of property.

Indeed, mandating a right to workplace democracy in this situation will not end exploitation, as John Roemer demonstrates. Even if capital is not permitted to hire labor, so that all firms are self-governing labor collectives, exploitation in the Marxian sense will still occur if labor is propertyless. This is because capital can exploit its advantageous position in the credit market to extract exorbitant interest payments when it loans capital to labor. With regard to the exploitativeness of an economy, "it does not matter whether capital hires labor or labor hires capital." Credit-market capitalism can be as exploitative as labor-market capitalism, which again suggests that democracy itself is not the cure for exploitation. This is why Roemer concludes that authoritarianism in the workplace "is of second- or third-order importance in maintaining capitalism and its injustices." 46

The point is this: if circumstances are such that prospective employees lack effective choice and are forced to consent to powerlessness in the firm, the proper way to undo this injustice is to enhance choice by repairing the background circumstances that unduly constrain it. The injustice is not undone if we simply guarantee equal outcomes in the form of political equality because the negotiation process is unfair, for self-government will not

46. John Roemer, Free to Lose: An Introduction to Marxist Economic Philosophy (Cambridge: Harvard University Press, 1988), pp. 90-107. 
render labor any less exploitable. The most that the exploitation objection might justify with regard to outcomes is the establishment of some minimum level of compensation below which the employment contract becomes invalid. This is the logic of minimum-wage and maximum-hour laws, which reduce freedom of contract in order to prevent exploitation of especially vulnerable groups. ${ }^{47}$ If labor consents to voicelessness at work due to exploitation, the community might establish a minimum degree of voice in the firm that cannot be bargained away, perhaps by abolishing at-will clauses or mandating unionization or even codetermination. But the right to workplace democracy is not the equivalent of the minimum wage, precisely because democratic voice is not the minimally acceptable compensation of voluntary labor but the maximum. To guarantee equal voice to all members of the firm is like guaranteeing each worker the same pay as the CEO. The obligation to prevent exploitation does not compel us to go that far. Society need only insist on a minimum degree of voice below which no employee may consent. The aim should be to block tyranny (abuse), but full-fledged democracy is not the only cure for tyranny at work.

Now consider the other version of the exploitation objection. Assume for a moment that subjection to capitalist management on the part of wage-labor is required. Here the robustness of consent is irrelevant, for subjects are simply conscripted regardless of choice. ${ }^{48}$ But even in this case democratic voice in the firm is not an entitlement of labor, although it would be in the management of the economy as a whole. This is because the "conscription" of labor in a capitalist economy only occurs collectively, not at the level of the firm but with regard to the class in its entirety. In this respect (and many others) the plight of slaves and proletarians differs, for slaves are conscripted individually by a specific owner while wage-laborers are only

47. On the logic of minimum-wage laws as a remedy for exploitation see Joel Feinberg, Harm to Self (Oxford: Oxford University Press, 1986), p. 79; and Thomas Hudson, "Immutable Contract Rules, the Bargaining Process, and Inalienable Rights," Arizona Law Review 34 (1992): 343.

48. According to Marx, the "surplus population of workers...forms a disposable industrial reserve army, which belongs to capital just as absolutely as if the latter had bred it at its own cost" (Capital, p. 784). In this sense workers are virtual conscripts, the capitalist equivalent of the Trotskyist labor army. 
conscripted as a class. Slaves are therefore morally entitled to voice-rights in the firm but conscripted wage-laborers only gain voice-rights in the management of capital as a whole. To claim that capital conscripts labor is to imply that capital is a public institution, the economic equivalent of the polity. Like residents, employees would therefore be entitled to an equal say in the management of capital, but only capital in the aggregate. Employees of any given capitalist firm would be no more entitled to self-government in that firm than civil servants are entitled to self-government in their particular agency. Dahl's proof does not hold for public employees because the third condition in the seven-point list is not met: that binding collective decisions ought to be made only by persons who are subject to the decisions. Police officers, for example, are not morally entitled to choose their bosses as if they were a self-governing collective because law enforcement is a public good, the property of the entire demos. The citizenry as a whole, given its subject status, has the right to choose the management of this agency, and police officers only share in that right in their capacity as citizens, not employees. The same would hold true if firms are nationalized as a public good. Citizens then acquire the moral right to choose management but the employees of each nationalized firm do not. Of course, the demos may decide to establish a democratic structure of governance in each firm, but that is a matter of discretion and would depend on a consequentialist calculation of the relative benefits of workplace democracy from the standpoint of the community as a whole.

On either version of the exploitation objection, then, the case for a moral right to workplace democracy fails. If we say that the subjection of labor is required ${ }_{2}$, the parallel case collapses because the subjection option is only hollow but not absent. The exploitation that undercuts the subjection option should certainly be undone, but voice per se will not rectify the injustice. By contrast, if we say that the subjection of labor is required ${ }_{1}$, the parallel case is sustained but employees are still not morally entitled to voicerights in the firm. The selection of management in this case becomes the privilege of the demos and its representatives, while employees in the firm become their public servants. 


\section{The Benefits of Consequentialism}

I conclude, then, that a moral right to workplace democracy on grounds of distributive justice does not exist. Employees are not like citizens because power is not claimed over them regardless of choice. For that reason employees cannot claim an equal share of power in the firm as a matter of right, because the norm of distributive justice to which Dahl subscribes is not violated. Unlike residents, employees possess a subjection option, which means that their subjection to authoritarian rule is a matter of discretion. Until this choice is shown to be invalid or irrelevant, their subjection cannot be described as an injustice.

It can, nonetheless, be described as undesirable. In addition to his moral-rights proof, Dahl develops a consequentialist argument for workplace democracy in A Preface to Economic Democracy. ${ }^{49}$ That argument has much going for it, though I do think he overstates the case..$^{50}$ Whatever its specific defects, however, Dahl's consequentialist argument does have the virtue of according more consistently with the democratic impulse that has animated his life's work. An argument framed in terms of what is desirable for the community leaves it to the demos to determine how the economy should be structured and what the rights and duties of employers and employees ought to be, without the impediment to popular sovereignty of moral-rights claims. If we take this approach, the distribution of power in the firm becomes an open question, and we can better accommodate the need for diversity and experimentation than the one-size-fits-all solution of moral rights.

This is in fact the approach Dahl took to the question before he worked out his theory of procedural democracy. In Politics, Economics, and Welfare, he and Charles Lindblom argued that with regard to the governance of the firm, "there do not seem to be any

49. Dahl, Preface to Economic Democracy, pp. 84-110.

50. For a powerful defense of workplace democracy on consequentialist grounds see Schweickart, Against Capitalism, pp. 88-136; for a more skeptical view see Henry Hansmann, The Ownership of Enterprise (Cambridge: Harvard University Press, 1996), pp. 66-119. For further reflections on the possible costs of mandatory democratization of firms see Robert Mayer, "Is there a Moral Right to Workplace Democracy?" Social Theory and Practice 26 (2000): 22-25. 
a priori grounds for preferring one organizational form to another or for prescribing any single solution for every enterprise." ${ }^{\prime 51}$ Likewise, in After the Revolution? Dahl claimed that in a rational society the governance of firms

would be looked upon as a concrete, practical question to be decided after taking into account the particular circumstances of the enterprise. Depending on these circumstances, the government of the enterprise could take many different forms. Just as people in such a society would think it irrational to believe that one form of democracy is invariably preferable to the others, so they would think it foolish to decide a priori that one form for governing economic enterprise is preferable to others in all circumstances. ${ }^{52}$

This rejection of a priori solutions, unfortunately, was lost from sight as Dahl sought to devise for his vision of a democratic economy "a stronger justification, one with a more Kantian flavor." ${ }^{53}$ But as we have seen, that neo-Kantian justification is in fact more vulnerable to refutation than the consequentialist argument it displaced.

51. Dahl and Lindblom, Politics, Economics and Welfare, p. 477.

52. Dahl, After the Revolution?, pp. 116-17. For a more recent expression of the same view see "Social Reality and 'Free Markets': A Letter to Friends in Eastern Europe," Dissent 37 (1990): 227.

53. Dahl, Preface to Economic Democracy, p. 111. 